\title{
The Exploration in Ways to Implement Ideological and Political Education in Normal School Students
}

\author{
Fan-lei Meng \\ Feixian School, Linyi University, Feixian, Shandong, P.R.China
}

\begin{abstract}
Being the future and the hope of the nation, college students has always been valuable talents, and also because of this, the ideological and political education of the college students has become a challenge and significant task of the contemporary era. Try our best to find the problems exists in the ideological and political education of the college students and work out the way to solve these problems should be our duty beyond all question.
\end{abstract}

Index Terms - Normal school students; Ideological and political education; Ways

\section{Introduction}

Being the future and the hope of the nation, college students has always been valuable talents, and also because of this, the ideological and political education of the college students has become a challenge and significant task of the contemporary era. Especially for normal colleges, whose aim is to cultivate teaching talents, the ideological and political education of the students is much more important. Try our best to find the problems exists in the ideological and political education of the normal school students and work out the way to solve these problems should be our duty without any doubt.

\section{Problems Exists in the Ideological and Political Education of Five-Year Normal School Students}

According to research, majority of the normal school students has chosen teaching as their lifelong occupation willingly, and has been making efforts to develop themselves fully so as to be competent for the teaching career. However, there are still problems-to-be-solved exists in the ideological and political education that we had been applying in the normal colleges, to this part, we should pay due attention .

\section{A. The contents of the education is not pointed enough}

The contents of the ideological and political education is to show us how to behave morally, it guarantees not only the fulfillment of the ideological and political education, but also the full development of the normal school students[1]. After applying the ideological and political education into students' daily life during recent years, we can see the contents of the education has grown from nothing, and has became much more comprehensive. However, there are still some problems to be solved, of which the most severe is that the contents of the education is not pointed enough.

\section{B. The ways of applying the education is too simple}

According to the research, the ways of applying the ideological and political education in the five-year normal school is way too simple. As to how to promote the ideological and political education among the normal school students, we still lack right institutional guarantee and effective measures. As to exploring the ways and enriching the tools we can use in applying education, we still hasn't form clear view or operative and realistic strategy.

\section{The join forces of boosting the education is not formed yet}

The ideological and political education among the normal school students is a systematic project, which demands not only the participation of the family, school and society, but also the cooperation of different parts among the ideological and political education system. Only in this way can we form the join-force boosting the ideological and political education ,furthermore to complete the task of the ideological and political education, to improve the normal school students' ideological and political quality[2]. However, it has not been very long since we apply the ideological and political education in five-year normal schools, the educational function and responsibility of the educators is still not defined very clearly. As a result, the lack of interaction, cooperation and communication among educators and other educating factors influence the fulfillment of the educational join-force, which is another serious problem exists in the ideological and political education of the normal school students'.

D. The lack of the studying motives

According to the research, while majority of the students are studying very hard and very well, some of them still do not have incentives to study hard, for example: individualism and utilitarianism is popular with some students in a way; some students do not have a clear and long-term studying plan and do not care about their academic records; some students do not listen carefully in class and even drop out frequently. To such kinds of phenomenon we should attach importance.

\section{E. Students' lack of certainty in occupational choice}

According to the research, some of the normal school students do not have clear career preference, haven't decided to choose the teaching job as their lifelong career. Some of them lack the share of responsibility for the fate of our country and the spirit of dedication.

\section{Select the Contents of the Ideological and Political Education in Normal College}

To solve these issues, above all we should set up advanced ideological and political education ideal, keep to the practical principles of the ideological and political education, and create new educational contents. On the premise that the educational contents, which embodies the purpose and the mission of the ideological and political education, is selected 
right, the fulfillment of the educational mission will be guaranteed, and the effectiveness of the education will be enhanced.

\section{A. Education of appealing students to take teaching as lifelong career \\ Professional ideal shows people's pursue for their future} career and for their professional goals, it propels people to achieve professional success intrinsically, is an important way to realize life ideal. Unlike average college students, for normal school students, they are studying here to become a teacher. We should lead normal students to set up the idea of becoming a qualified teacher and to make their endless efforts to make it[3].

\section{B. Education on thanks-giving}

Being the essential part of the ideological and political education in normal school students, education on thanksgiving is the process that educators set up a certain atmosphere so as to educate the students emotionally, morally and teach them the sense of responsibility through certain educational methods[4]. By applying the education of thanks-giving to students, they will learn to care about themselves and other lives, and come to understand thanks-giving, master thanksgiving, practice thanks-giving.

\section{Education on professional ethics of teacher}

Being the transmitter of human scientific culture knowledge, social thoughts and morality, being the inheritor and disseminator of human cultural heritage, teacher shoulders the responsibility of spreading knowledge, of discovering, cultivating and training talents. Being active, strong imitators, the young students are waiting to be molded into whatever shape the educators want[5]. In daily life of teaching, the ideological moral characters, work style, behaviors and social attitudes of teachers will influenced the students subtly. Teacher's position in teaching and traits of young student demands that a teacher must have lofty professional ethics, so as to meet the requirements of social development and the deeds of talent cultivation.

\section{Education on professional ability of teacher}

The teacher's professional ability is a certain faculty of smoothly accomplishing teaching duties formed among educational teaching activity. It is a comprehensive reflection of teacher's professional quality, specialized knowledge and ability to educate people. If such kind of ability is neglected, the development of teachers would become water without source and tree without root. The normal students will be outstanding teachers and educators in the future, not only should they set up the great idea of devoting their whole lives to education, cultivate noble professional ethics, but also ought to improve their professional ability. To carry out ideological and political education in normal college students, ideological education should be combined with the improvement of teacher's professional ability, both the ideological and practical problems should be solved, the actual effect of the ideological and political education should be strengthened, eventually we will be able to promote the full development of the normal students. In a word, in ideological and political education of normal students, the education on professional ability of teacher is one of important contents.

\section{Explore Effective Ways to Implement Ideological and Political Education in Normal Students' Daily Life}

Happened outside the classroom, with the aim to achieve the goal and task of ideological and political education, and to spread the content of it, the ways to implement ideological and political education in normal students is kind of method to educate, manage and serve normal students particularly in their daily life, is also the channel the whole process has been through[6]. Considering the traits and laws of the formation and development of normal students' moral character, combined with their thoughts and actions, to strengthen the actual effect of the ideological and political education in normal students ask us to study in multiple perspectives, such as practice education, public media, school campus culture, the demonstration role of school educators and students' selfeducation.

\section{A. Carry out social activity}

Being an important part of talents cultivating at colleges, social activity is the extension and sublimation of classroom education, is an important way to strengthen and advance the ideological and political education in university students. Social activity will help normal students to learn about national situation and public sentiment, promote students to realize the attraction of being a teacher, deepen and enhance their educating and teaching abilities, convince them that selecting teaching as their lifelong career is worthwhile. Taking cultivating objectives of normal students and their physical and mental characteristics into account, we should actively explore such activities as observation-teaching, aidthe-poor practice teaching program and experience rural grassroot life.

\section{B. Make good use of new media}

Recently, traditional mainstream media, including school newspapers, campus broadcasts and TV stations, have gained great development and have formed a relatively balanced structure. In the meanwhile, with the rapid development of the science technology, the new media, kind of much more innovative, based on digital technology, features interactive transmission, has more influence on society, especially on college campus where the young people gathers. New media has given us a new approach to implement the ideological and political education ideological and political education among college students.

\section{Create a platform for campus culture}

The campus culture is the whole name of the material culture and moral culture with the long-term developing process in education, teaching, scientific research and management of a campus. It originates from university setting, takes students as priority, teachers as leadership, aims to promote the comprehensive development of students. The campus culture falls into three aspects: material culture, which consists of campus building design and teaching facility; 
institutional culture, which contains the rules and regulations that adjusts and regulates the relationship between managers and the managed; spiritual culture, including campus spirit, valuable activity, pursuing ideals that are commonly acknowledged and are formed among the long-term developing process of school. Being an important way to improve students' ideological and political education, the campus culture should be treated scientifically, and the establishment of it should be valued, the platform for campus education should be built, all the above-mentioned methods will help to make the ideological and political education in normal students' daily lives more aimed and effective, to improve the ideological and political quality of the students[7] .

D. Emphasis on educator's role of "acting as an example"

It is necessary to do so if we want to achieve actual effect in ideological and political education in students' daily lives. "Acting as an example" means you practice what you preach. When implementing the ideological and political education into students' daily lives, the educator's behaviors has demonstration and enlightenment effect for the students. So it's necessary for educators to act as students' moral model, and helps to improve the ideological and political quality of students[8].

\section{E. Guide students to enhance self-education}

With the further development of our market economy, the deepening of the reform and opening up, college students have wakened up their principal consciousness, and have formed views of themselves on everything. Self-education comes to take a bigger role in college students' ideological and political education.

\section{Summary}

Strengthening normal students' ideological and political education is beneficial to the socialism spiritual civilization developments, to the sustainable development of society and the balanced development of education, and to the strategy of developing our country with education and talents. In college students learn to be independent, strengthening the ideological and political education in normal college students will help to foster the formation of student's ideology, will help them to understand themselves, appreciate themselves and then to advance themselves, so as to foster student's active mood, and promote their mental health[9].

\section{Acknowledgment}

The authors wish to give their sincere thanks to the editor and the anonymous referees for their valuable suggestions and helpful comments which improved the presentation of the paper.

\section{References}

[1] Xiong Jiansheng, The Hierarchy of Contents of Ideological and Political Education. 9Journal of Ideological \& Theoretical Education,2006.

[2] Wei Xiaowen, Comparative Studies in Ideological and Political Education of China and U.S.A. 9 Dalian University of Technology, 2003.

[3] Liu Yueling, Research on The Teaching Methods of The Education of College Students' Ideals In New Era. Science \& Technology of Xi'an, 2005.

[4] Wang Feng, The Exploration of Moral Function of Ideological and Political Education 2 Journal of Anhui Institute of Education,2003.

[5] Fu Jianping, The professional Ethics of Tuition-free Normal Pedagogical Students. 1 Journal of Chongqing Vocational \& Technical Institute, 2008.

[6] Zhang Xuemei, The Study on The Cultivation of Normal Students' Ideological and Moral Development. ortheast Normal University, 2009.

[7] Liang Guidong, The Potential Function of Campus Culture. 10 Tianjin Education, 2007.

[8] Xiao Yaogen, The Study of Methodology for College Students' Mental Health Education Wuhan University,2003.

[9] Deng Huchuan, Reflections on Ideological and Political Education of Tuition-free Normal Pedagogical Students. 5 Journal of Ideological \& Theoretical Education,2010. 